УДК 726+299.572(571.56) Яковлев А. И., Федорова А. Р., Егоров А. Ф.

\title{
О "новых" этнокультурных сооружениях Якутии
}

В Якутии традиционное ритуалы, образ жизни, вера и культура якутов существует и развивается до сих пор, но её новые формы (в рамках данной статьи - "новые" этнокультурные сооружения) определяются через призму понятия традиционализма, ревитализации традиционной культуры и её отражение в культурном ландшафте. Основное внимание будет уделено тому, как в культурном ландшафте республики раскрывают и интерпретируют традиционную культуру, как её фрормы репродуцируются в массовых культурных мероприятиях городской и сельской среды и, самое главное, как они обретают свою новую форму в повседневной жизни жителей Якутии. Для раскрытия этого явления помимо классических методов сбора полевых материалов мы использовали глубинное интервьюирование местных жителей (экспертное интервью), метод включенного наблюдения.

Темой культурного ландшафта в российской науке занимается большой пласт исследователей, стоит отметить работы Н. В. Кузьминой, в которых ставится вопрос формирования культурного ландшафрта как постоянного процесса семиозиса, инструментом чего в российских мегаполисах выступает символико-семиотическое проектирование [9]. Другой работой является статья Д. А. Дирина, в ней он приводит подробный историографический обзор работ исследователей по теме культурного ландшафта [7]. Так, в данной работе под термином "культурный ландшафт" мы понимаем сложную территориальную систему, в которой главную и определяющую роль играет человек и общество [4]. Стоит отметить, что исследование культурного ландшадрта в Якутии, напрямую связано с изучением традиционной культуры якутов и её ревитализацией.

В свою очередь, можно проследить особенности в изучении этнокультурных сооружений современных якутов, так большую роль на их изучение сыграли классические труды по изучению традищионной культуры якутов, а именно труды Р. К. Маака [11], А. Ф. Миддендорфа [12], В. Л. Серошевского [14] и многих других исследователей XIX в., в работах которых даются одни из первых попыток описать и проанализировать традиционные якутские сооружения. В работах авторов XX-XXI вв. стоит отметить работы следующих авторов: М.М. Носова [13], Ф.М. Зыкова [8], А.И. Гоголева [6], которые продолжили изучение традиционных типов жилища у якутов (бала5ан, ypaha) в жизненном пространстве якутов.

Статья опирается на полевой материал, собранный в период 20172019 г. в Западных и Центральных улусах, Верхоянском, Усть-Майском, Абыйском районах, городе Вилюйске, Якутске Республики Саха (Якутия) в рамках грантов Президента РФ и РФФИ в ходе изучения вопроса трансдормации традиционной культуры. В статье упор сделан на описание этнокультурных сооружений современных якутов. Современным этнокультурным сооружениям якутов можно отнести ыhыıах түһүлгэтэ (ысыах тюсюлгятя) места

(С Яковлев А. И., Федорова А. Р., Егоров А. Ф., 2021

ЯКОВЛЕВ Айтал Игоревич, канд. ист. наук, доцент кафедры "Всемирная, отечественная история, этнология, археология" Северо-Восточного федерального университета им. М. К. Аммосова (2. Я кутск). E-mail: aytalyakovlev@mail.ru

ФЕДОРОВА Айталина Родионовна, младший научный сотрудник Института гуманитарных исследований и проблем малочисленных народов Севера СО РАН, аспирант кафедры "Всемирная, отечественная история, этнология, археология" Северо-Восточного федерального университета им. М. К. Аммосова (г. Якутск).

ЕГОРОВ Александр Федорович, аспирант кафедры "Всемирная, отечественная история, этнология, археология" Северо-Восточного федерального университета им. М. К. Аммосова (2. Якутск). 
проведения традиционного якутского праздника ысыах, Арчы Дьиэтэ (Арчы Джиетэ - Арчь - якут.очищение, Дьиэ - якут. дом). ыһы ах түһүлгэтэ является своеобразным комплексом культовых сооружений современных якутов, где представлены все виды якутских традиционных сооружений или стилизованные под них строения (бала5ан - якуткая юрта, ураһа - традиционное конусообразное строение из жердей, покрытых берестой, якутское летнее жилище, сэргэ - коновязь, ритуальный столб). Арчы Дьиэтэ - это отдельное здание или отдельные здания примкнутые друг другу, создающие один архитектурный ансамбль.

В данной статье мы будем делать упор на Арчы Дьиэтэ, так как они появились совсем недавно, обладают мультифонкциональным характером внутреннего содержания, т.е. все мероприятия проводятся вокруг или около обряда Алгыс. Главное отличие Арчы Дьиэтэ от ыһ ıах mүhүлгэтэ это то, что последние имеют чисто обрядовые функции и имеют культовое значение для основной массы современных якутов.

Сложное понятие этнокультурный традиционализм в рамках данной статьи мы раскрываем, опираясь на следующие понятия: "этнокультурные сооружения современных якутов" и "культурный ландшафрт", которые будут рассматриваться на плоскости исторической антропологии. Понятие "ревитализация традиций" (буквально оживление традиций) мы будем использовать для описания всего современного состояния социокультурных процессов в $\mathrm{Pe}$ спублике Саха (Якутия), а также для объяснения целого комплекса проблем развития традиционной культуры в условиях культурной глобализации. Процесс характеризируется широкой гаммой проявлений, как в повседневной жизни жителей городов и сел, так и в государственной региональной политикой в Якутии.

Статья будет состоять из двух частей - в первой мы приведем описание этнокультурных сооружений современных якутов, вторая часть статьи будет состоять из описания их функциональной части. В третьей части мы дадим объяснение связующим компонентам современного культурного ландшафта и ответим на вопрос, почему этнокультурные сооружения современных якутов являются проявлением традиционализма в Якутии.

Перед тем, как перейти к описанию современных этнокультурных сооружений современных якутов, стоить дать краткую справку об основных видах традиционных якутских построек. В дальнейшем при описании "Арчь Дьиэтэ" мы будем опираться на них, как на фундамент архитектурного вдохновения при создании облика новых этнокультурных центров.

В традиционной якутской культуре существует несколько видов типовых построек: ураһа, бала5ан (юрта), многоугольный сруб, четырехугольный сруб. Остальные постройки, считающиеся традиционными, как правило, используются как хозяйственные, и их мы в данной статье приводить не будем.

Бала5ан (юрта) - одна из самых древних типов якутского зимнего жилища. Это четырехсторонняя деревянная постройка, стены которой составляются из бревен, слегка наклоненных внутрь. Крышу покрывали одним или двумя слоями лиственничной коры, а затем землей. Балаганы зажиточных людей могли иметь пристройки, часто к дому также был пристроен хотон (помещение для скота). Вход в жилище непременно должно быть обращено на восток $[14$, с. 339].

Ураһа - конусообразная летняя постройка. Характеризовалась более нарядным обликом, в сравнении с другими низкими и темными строениями. Сооружается ypaha из 10-12 столбов по кругу, они могли достигать высотой 2 метров, а в землю закапываться на глубину 1 метра. Покрывалась конусовидная постройка из жердей сверху берестой, которую часто украшали резными узорами или нашивкой [8, с. 53].

Многоугольный сруб - достаточно редко встречающийся вид деревянного жилища. Они наиболее редко описывались этнографами, но при этом удивительный образом оказали, пожалуй, наибольшее влияние на современную этнокультурную постройку. Как правило, такое сооружение имеет 6 или 8 сторон, встречается как с пристройкой, так и без [8, с. 37]. В целом облик этой постройки выглядит как многоугольная призма, каждая из стен которой выстроена из горизонтально уложенных бревен. Крыша в некоторых случаях покрыта землей, как упомянутый выше балаган, а в других представляет из 
себя многостороннюю пирамиду, которая является как бы продолжением основной части жилища.

Приведем описание современных сооружений Арчы Дьиэтэ (якут. Дом Очищения) в хронологическом порядке их постройки. Для описания данных сооружений мы опираемся на их архитектурные особенности (внешняя атрибутика), которые выступают маркером представлений о своей культуре и ее облике, и функциональном содержании (внутренняя атрибутика).

1) Первое подобное сооружение было открыто в Сунтарском улусе в 1999 г. "Самый первый храм якутской религии" получил название Aüыıы Apчьıта (Aйыıь - якутские боги, Apчьı - охрана, в сакральном смысле). Проект здания подготовила архитектор Альбина Гурьева. Одноэтажное основание постройки сверху выглядит как многоугольник с четырымя пристройками, которые в ансамбле образовывают форму креста. По центру сверху расположена многоугольная башня с округлым куполом голубого цвета.

В целом здание внешне мало что имеет общего с типично якутской архитектурой и якутским стилем. Тем не менее этим событием и было положено начало активного строительства этнокультурных сооружений современных якутов в районах республики. Во многих районах стали возводиться этнокультурные центры - Арчьь дьиэтэ (Дом ритуального очищения), Айььь дьиэтэ (Дом богов), Олонхо дьиэтэ (Дом Олонхо), Айыıь арчыла (Божественная охрана) и т.д. Данные этнокультурные сооружения могут носить разные названия, они в большинстве случаев выполняют одни и те же функции.

2) В 2002 г. был построен Дом Арчы в столице Республики Саха (Якутия) - Якутске. Здание состоит из трех соединенных между собой сооружений по внешнему облику очень напоминающим одну из форм традищионного якутского жилища - многоугольные срубы, каждый имеет 8 углов. Такой тип в традиционное время был распространен преимущественно в Якутском округе и по Якутско-Верхоянско-Колымскому тракту и имел как правило шесть или восемь углов [2, с. 37-38]. Нижняя часть сооружений состоит из прямых восьмиугольных конструкций, затем основная часть зданий напоминает восьмиугольную усеченную пирамиду с плоской крышей. На крышах имеются полусфрерические остекленные возвышения с навершием в виде символа мирового древа Аал Лук Мас.

Арчьц Дьиэтэ в городе Якутске содержит в себе намного больше символов якутской культуры, чем ее предшественник. В других источниках упоминается, что один из главных божеств в мифологии якутов - Уордаах Джесегёй - якобы жил в старинном шестиугольном бревенчатом жилище, обшитом снаружи конской шкурой $[2$, с. 41]. Эти данные фольклора дают нам основание полагать, что в древности у якутов многоугольные постройки служили в качестве жилых, хозяйственных, культовых построек и военных укреплений [2, c. 41]. Помимо этого, в архитектуре здания использована масса других фрунда-

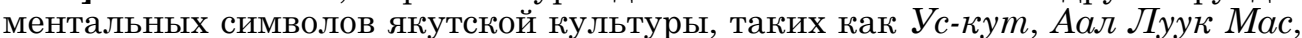
символы и изображения культа коня.

3) Построенный в 2010 г. деревянный Арчы Дьиэтә в селе Чурапча в основе также сооружен в форме восьмиугольной призмы с восьмисторонней конической крышей. По четырем сторонам имеет небольшие пристройки с наклонными стенами. Планировка здания крестообразная. Железное навершие на конической крыше имеет форму символа "лапка гагары".

4) Центр Олонхо в Сунтаре, построенный в 2011 г., является муниципальным бюджетным учреждением. Белая двухступенчатая ураса нижний ярус которой имеет форму усеченной многоугольной пирамиды, украшенная сверху полосами красного, желтого и синего цвета, а верхняя часть меньшая по диаметру многоугольная ураса, по четырем сторонам и на навершии которой возведены деревянные небольшие украшения в виде Аал-лук мас. Также впереди и сзади основного строения имеются продолговатые пристройки, стилизованные под балаган - с наклонными стенами используемые в качестве технических и административных помещений. Центр декорирован резными деревянными украшениями как внутри, так и во дворе, в том числе сэргэ (якутскими коновязями).

5) В 2012 г. началась постройка частного Дома Арчы в поселке Эбях Среднеколымского района. Стройка была начата по инициативе главы наслега и помогали в строительстве культурного центра всем селом. Внешне 
здание имеет форму классического якутского балагана. Это трапещиевидная деревянная постройка из бруса, бревна которой расположены вертикально и под небольшим наклоном. Крыша у такого сооружения бывает плоской и кровлей ее выступает земля с дерном. Подобного рода небольшой Дом Арчы построен был также в селе Аргахтах Среднеколымского района. Постройка деревянная, имеет вид балагана, плоскую крышу и облицована железным профрлистом.

6) Дом Олонхо в Нижнем Бестяхе было создан и построен в 2013 г. по дизайну архитектора Шишигина И. И. Главенствующее помещение выполнено в форме многоугольного сруба с восьмью углами, украшенными железными харысхалали (оберегами), а навершием послужило железное сэргэ с четырьмя лошадиными головами. Второе помещение имеет форму усеченной пирамиды и должно, по-видимому, напоминать балаган. Третье помещение является объединяющим, в нем смешивается административная и культурная роль данного здания. В данном помещении располагается районный отдел ЗАГС.

7) Дом Олонхо в городе Вилюйске был построен в 2014 г. в самом центре города. Основание здания имеет 8 сторон и форму прямой многоугольной призмы, крыша же разделена на две части по степени наклона, где нижняя ее часть напоминает усеченную восьмиугольную призму, а вторая верхняя более тяготеет к восьмисторонней пирамиде. По четырем сторонам имеются пристройки, и опять же форма здания сверху напоминает крест. Каждая сторона крыши декорирована резными круглыми харысхалали (оберегами). Навершие выполнено в виде символа "лапка гагары".

8) В 2014 г. в Намцах в рамках VI Спортивных игр народов Якутии открылся Дом Олонхо им. П. П. Ядрихинского-Бэдьээлэ. Комплекс, состоящий из двух балаганов и двухуровневой урасы, возведен в самом центре села Намцы недалеко от площади Ленина. Местные мастера изготовили убранство и мебель Дома в национальном якутском стиле и установили священное дерево Аал Луук Мас. Достаточно просторная двухэтажная ураса с шестью углами и остекленным конусом. Также на территории Центра имеются два якутских балагана и священное дерево Аал Луук мас.

9) В исправительной колонии № 7 в 2015 г. состоялось открытие Дома "Айыы Арчыта". Его строительство имело своими целями повышение эфрфективности воспитательной работы с осужденными, просвещения и духовно-нравственного развития содержащихся граждан, в том числе через приобщение к традициям якутского верования "Аар Айыы". Строительство культового сооружения якутского верования "Аар Айыы" - Дома Айыы Арчыта, велось в течении пяти лет и осуществлялось на средства, собранные за счет благотворительной помощи и пожертвований общественности, а строительные работы проводились руками заинтересованных осужденных, содержащихся в ИК-7.

Необходимо отметить, что на территории колонии прежде уже были возведены православный храм и мечеть. Таким образом, с открытием Дома Айыы Арчыта в учреждении создан уникальный прецедент в виде ансамбля трех зданий - представителей разных религиозных конфессий.

10) В селе Ботулу Верхневилюйского района здание называется "Айыьы Хараана" (Дом Бога). Здание построено по частной инициативе жителя села Боескорова Т.С. в 2016 г. Строение имеет облик шестиугольного здания с продолговатым коридором входом. Сверху планировка напоминает замочную скважину. Обшивка вертикальная по типу якутского балаган (традиционное жилище якутов) из деревянных полукруглых досок. Фундамент обшит горизонтально имеется 4 окна по трем сторонам основной конструкции и одно в коридоре входа. Рамы окон выполнены в виде якутского чепрака. Наверху имеется что-то вроде башни с окнами и навершие из железа, изображающее символ "лапа гагары". Крыша отделана профлистом. Выход располагается на Северо-Восток. Внутри здание богато украшено различными шкурами, резными узорами, чоронами (ПМА. Верхневилюйский улус, с. Ботулу. Т. С. Боескоров. 1966 г. р. (июнь 2017 г.)).

11) В селе Верхневилюйск Дом Арчы был введен в 2017 г. Сооружен из бруса и облицован деревянными плоскими панелями вертикально. Здание Вехневилюйского Дома Арчы стоит, примкнувшись к муниципально-бюджет- 
ному учреждению "Едюгейский культурно-досуговый центр". Дом Арчы имеют форму урасы, но изгиб сторон к верхушке не плавный, а имеет три грани, так как стенки выполнены из прямых досок. Здание имеет 8 сторон и внутри 8 столбов по местам состыковки сторон. В центре помещения традиционно имеется очаг (холумтан) для проведения алгыса, а камелек находится не в главном помещении, а в широком переходе между домом арчы и культурно-досуговым центром. В помещении имеется отопление и санузел, что очень важно и, по свидетельствам информанта, именно этот момент "экономии расходов бюджета муниципалитета" был важным при решении строить пристройку к основному зданию сельскому культурно-досуговому центру, а не отдельное здание.

12) Стоит отметить Олонхо Дьиэтэ (Дом Олонхо) в Нюрбе. Это деревянная постройка в целом, как и в г. Якутске, напоминает многоугольный сруб. Сбоку есть вход с южной стороны, где располагаются два технических помещения, одно для охраны и гардероба, второе с кухней и телевизором для работников, имеются также отдельные помещения для администрации, туалет и хозяйственные помещения. Центральное помещение крупное, имеет 16 углов. Сверху по центру вверх возвышается башня. На второй этаж восходит лестница, которая образует что-то вроде балконов, на которых можно стоять и смотреть вниз на мероприятия, проходящие в общем зале. Внутри инвентарь из посуды, музейных экспонатов, оружия, традиционных хозяйственных принадлежностей, музыкальных инструментов, имеется также камелек. На момент посещения Дома Олонхо проходила подготовка к Ысыаху, поэтому он временно не фонкционировал. Держат сооружение изнутри 8 столбов. Украшено изнутри резными узорами. Снаружи по сторонам здания стоят три массивных прямоугольных сэргә, судя по всему, сделанных из досок и полых внутри с шейкой и навершиями в виде чоронов. Имеются евроокна, декоративные элементы из железных листов. Интересна конусообразная верхушка здания с семью сторонами, украшенная подсветкой и железным навершием в виде якутского Мирового Древа (Аал Луук Мас) с тремя ветвями по всем четырем сторонам, стоящее на железном бриллианте. Здание отапливаемое. Сверху обшито деревянными панелями.

Поблизости на этом же участке располагается другое административное здание, которое выглядит как три шестиугольных помещения, которые соединены между собой и крыши которых имеют форму урасы, у каждой из которых также имеется навершие в виде мирового древа. Во дворе стоит комплекс сэргэ из трех коновязей с навершиями в виде алмаза, чорона и головы лошади.

13) Выбивается из этого списка Арчы Дьиэтэ в пригороде города Якутска - в отличие от вышеописанных, он частный и стоит на частной территории. По внешнему виду это вполне обычное прямое двухэтажное деревянное здание, без каких-либо затейливых форм и украшений. От большого количества других частных домов вокруг его отличает только два навершия на крышах в виде шпиля и бегущей лошади.

Внутри здания на первом этаже находится музей, в котором особое место занимают книги Владимира Кондакова, также есть его шаманские костюмы, бубны и другие атрибуты якутской религии. На втором этаже расположены библиотека и комнаты для лечения традиционной медициной. К слову, в этом же здании расположен офис Ассоциации народных целителей Якутии.

Касаемо юридического статуса подобных сооружений они бывают двух типов: муниципальные и частные. Муниципальные, как правило, бывают крупными, находятся в улусных центрах, в самом сердце города или села, имеют штатных работников и мультифункциональны, большинство услуг предоставляют на платной основе. Частные этнокультурные сооружения располагаются на частной территории, имеют меньшие размеры вследствие меньшего бюджета и часто монофункциональны.

По фрункциональной части этнокультурных сооружений современных якутов надо отметить, что во многих указанных районах (улусах) и городах этнокультурные сооружения мультифрункциональными и не замыкаются на обрядовых действиях. И фрункциональное заполнение указанных зданий можно условно разделить на две части: обрядовые (культовые) и утилитарные функции. В рамках полевых исследований в различных улусах Западной и Центральной Якутии было установлено, что кроме обрядового церемониа- 
ла якутские Дома Арчы становятся пространством для множества других мероприятий. На наш взгляд, утилитарная функция Домов Арчы исходит из насущных проблем и трудностей, существующих в сельской и городской среде, и конкретно упирается в вопросы содержания здания, когда культового фуункционала становится недостаточно для крупной постройки, как правило, в центре населенного пункта. Все описанные в первой части статьи здания стоят на балансе муниципальных властей (районных и городских управлений культуры), кроме одного.

Например, в городе Якутске администрация Дома Арчы, позиционирует здание не как религиозное учреждение (культовое здание), а как культурно-досуговое учреждение. Также и в Доме Олонхо в городе Нижний Бестях смешиваются как проведение частных занятий по якутской культуре или предоставление услуг целительства, так и проводится выдача актов государственной регистрации брака. Здание было построено в 2016 г., тепло еще не проведено, свадебных алгысов (обряд благословения) и крупных мероприятий еще не проходило. В данном помещении встречают важных гостей и проводятся различные мастер-классы народного творчества.

Как отметил респондент из с. Ботулуу Верхневилюйского улуса Боескоров Т.С., построенный для жителей деревни им самим Айыы Хараана (Дом Айыы - Aйыьь белые божества в якутских религиозных воззрениях) предназначен не только для культовых религиозных обрядов, но и для собрания местных жителей. "Мужчины могут собираться для обсуждения мунха (традиционный вид коллективной подледной рыбалки на озерах). Женщины, например, для коллективных работ, как шитье, заготовка сырья для рукоделия" (ПМА. Верхневилюйский улус, с. Ботулу. Т. С. Боескоров. 1966 г. р. (июнь 2017 г.)). Практически такие же ответы и описания этнокультурных coоружений современных якутов Арчы Дьиэтэ, где упор делается на утилитарное, повседневное использование зданий - место собраний, проведение культурно-просветительских мероприятий. Такое можно наблюдать практически везде по Якутии. Знаменателен фракт того, что о постройке Арчы Дьиэтэ сельские жители начинают говорить в тот момент, когда в деревне строят или построен современный типовой культурно-досуговый центр из бетона и стекла. Местные жители оценивают его тем, что он не "сахалыы кута суох", "тас көстүүтэ атын" (нет якутского духа, внешне не соответствует), т.е. можно определить, что новые каменные здания не вписываются в культурный ландшафт якутских сел.

Обрядовые функции упираются в традиционные для якутов формы обрядов - очищение (Арчьъ), благословения (Алгьı). И при описании обрядов (наличие огня, обрядовая атрибутика, семантика движений) можно увидеть ссылку на древние традиции якутов, отмеченные в трудах путешественников и этнографров, и распространенных повсеместно по всей территории Республики Саха (Якутия). Однако некоторые формы обрядов (мужской осуохай, воскресный мужской алгыс), время проведения обрядов (осуохай в зимний период, или в не специфических местах для традиционного якутского кругового танца) можно отметить, как видоизмененные традиции, которые были привнесены в силу потребностей и повестки времени.

Посетив многие Дома Арчы и побеседовав с их администрацией и застройщиками, можно сделать вывод, что большинство из их внешней и внутренней атрибутики бывают спроектированы на основе сакральных символов якутов. В исследуемых нами домах Арчы часто используются такие символы национальной культуры как:

- солярные символы, в том числе ус-куm ("три души" символ якутской души), сюда же можно отнести и харысхалы - солярные символы, несущие функцию оберега;

- лировидные узоры и растительные узоры, которые символизируют плодородие. Лировидная форма является и символическим образом пробивающегося из земли растения. Его рассматривают как мировое древо - древо жизни, является символом роста, развития, стремления к свету. Лировидный мотив в орнаментальном искусстве символизирует благословение на развитие и процветание в Срединном мире, поэтому обязательной традицией в вышивке этого орнамента является его симметричность и вертикальное расположение $[15$, с. 80]. 
Обязательным атрибутом является изображение мирового древа якутов - Аал Луук Мас, которое в якутском фольклоре выступает мировым древом, объединяющим Нижний, Срединный и Верхний мир.

Символы, связанные с лошадью и коровами; к данной категории относятся многие элементы якутской материальной культуры, в том числе предметы, связанные со скотоводством и коневодством, конский волос, изображения лошади.

Многие архитектурные решения стоят на таких столпах традиционной культуры якутов, как тройственность мира, культ огня, культ лошади, сакральность чисел. Если какие-то идеи черпаются из традиционного прошлого, то некоторыми вдохновляются от более крупных религий. Так, мы у большинства перечисленных нами этнокультурных сооружениях современных якутов наблюдаем навершия. Причем изображаться оно может в совершенно разных символах: Аал Луук Мас, лапка гагары, сэргэ (ритуальный столб), лошадь. Примечательно, что все архитектурные решения, внутреннее убранство и украшения зданий проходят обсуждение с местными жителями села, знатоками традиционной культуры.

Таким образом, можно сказать, что в определенном смысле архитектурные образы религиозных построек черпаются из ассоциативных представлений, связанных с традиционной символикой, представлений о своей родной культуре через живые образы, возникающие практически на ментальном уровне, и связаны с глубинными представлениями о своей традиционной культуре, заложенными с раннего детства и не только воспитанием, но и другими институтами социализации и инкультурации человека.

Культура Якутии является примером мультикультурности - вековой контакт и культурный обмен с коренными народами Севера, русской культурой всегда был очень тесным, якутская культура на современном этапе вбирает в себя и часть культурной глобализации. На бессознательном уровне происходит определенный синтез культур, выявляющийся в ассоциациях, которые мы наблюдаем в развитии культурного ландшафрта. Современные социально-экономические процессы (урбанизация в Республике Саха (Якутия), промышленное освоение края, развитие цифровых технологий) изменяют культурный ландшафт, происходит наполнение его этнокультурными компонентами, или, другими словами, "ренессанс" традиционной культуры [2], что, в свою очередь, связано с ответом на вызовы глобализации современного мира. Так, в Республике Саха (Якутия) основой культурного ландшафта считается сельская среда, где сохранились элементы традиционной культуры. В городах, в свою очередь, в связи с глокализацией данные проявления хоть и наблюдаются, но в основной своей массе "теряются" на фоне мультикультурности городского населения.

Функционально этнокультурные сооружения современных якутов не имеют отличия от традиционных видов якутских сооружений, относящихся к культовым объектам. Яркий пример сэргэ - определяется как бытовая коновязь, но также имеет и религиозно-обрядовое значение, выступая как ритуально-культовый столб. Это можно объяснить спецификой культуры жизнеобеспечения якутов, которая до сих пор зависит от природно-климатических условий, сохраняя свою сезонность. При суровых природно-климатических условиях простые вещи или здания всегда использовались и используется как многофункциональные предметы и пространства.

Можно отметить, что массовое для Якутии строительство этнокультурных сооружений Арчы Дьиэтэ на волне возрождения традиционной культуры и традиционных верований является одной из форм глокализации. Строительство Дома Олонхо финансировалось движением "Добрые дела". Бригада, собранная из представителей Горного, Мегино-Кангаласского и Хангаласского улусов, начала работу с весны 2012 г. А в 2010 г. местные жители провели марафон, где было собрано 468 тысяч рублей. Эти средства ушли на возведение оклада здания. Это проявляется также в создании некоммерческих общественных организаций, ставящих своей задачей возрождение традиционной культуры и веры якутов, воспитание молодежи на основе нравственных и патриотических устоев, которые, по их мнению, присущи настоящему якутскому обществу и основаны на традициях якутов. Согласно данным информационного портала Министерства юстиции Российской Федерации, на территории 
республики официально зарегистрировано как минимум 5 местных религиозных организаций, 3 из которых зарегистрированы в г. Якутске [16]. Вышеупомянутые общественные организации и интернет сообщества в этой связи становятся местом коммуникации и катализатором рефлексий относительно социокультурных процессов в Якутии. Данные редлексии в большей мере можно рассматривать как способ компенсации, в вопросе самоидентификации и сохранения привычной социокультурной среды. Ярким примером данной компенсации можно рассматривать такие явления, как "мужской осуохай" и "мужской алгыс". Которые пользуются большой популярностью у местного населения [3; 17]. Конечно же, среди населения имеется двоякое отношение к данным мероприятиям, однако стоить отметить, что вышеупомянутые явления являются ярким показателем интереса к традиционной культуре и способом ее сохранения, самоидентификации современных якутов в глобальном мире.

Ресурсом в данном случае следует считать этничность, которая выражается в интересе к традиционным верованиям и культуре. В кейсе мужского алгыса ритуал является способом создания и стабилизации идентичности. Общая религиозная практика формирует чувство причастности и коллективной идентичности. $K$ тому же для молодых мигрантов из села участие в мужском алгысе несёт за собой способ социализации к мультикультурной среде Якутска.

Стоить отметить, что в сети Интернет, благодаря мессенджерам и социальным сетям, имеется множество сообществ с ориентацией на сохранение традиционной культуры, пропаганды здорового образа жизни и спорта, популяризации якутской традиционной веры. Приведенные примеры говорят нам о том, что у многих представителей якутского народа, особенно молодежи, есть мотив к компенсации относительно самоидентификации. В частности, город Якутск как центр Республики, место коммуникации множества культур представляется тем местом, где самоидентификация народа может быть под "угрозой".

В данном случае, можно предположить, что идет упор на историческую память и коллективное бессознательное, т.е. традиционные социокультурные коды воспринимаются лучше и приближенны к привычному образу жизни, а также легко вписывается в картину мира этнофрора, тем самым не нарушая его привычный уклад жизни. В этом же ключе может играть реакция и редрлексия этнофоров на быстро меняющуюся действительность, например, на проблему адаптации внутренних и внешних мигрантов, взаимосвязи между сельской и городской средой.

В данном случае общество (или социальная группа) не успевает приспосабливаться к тем или иным изменениям, тем самым есть угроза для маргинализации социокультурной жизни и жизненных приоритетов. В этом случае, по мнению В.Г. Бабакова, этнофоры предпочитают "повернуть время вспять" [1] и обратиться к традиционным этническим ценностям. Что непосредственно можно отнести и к строительству новых этнокультурных сооружений, которые вписываются в "традиционный якутский ландшафт". Что также можно подтвердить словами К. Леви-Стросса, по его мнению, мифо традиционной культуры понятны общности без каких-либо объяснений и являются коллективными [10].

Таким образом, мы говорим, что Арчы Дьиэтэ - новые этнокультурные сооружения современных якутов - являются местом концентрации традиционалистских сил.

Дома Арчы не являются утилитарно культовыми сооружениями, где проводятся только традиционные обряды якутов, а носят, как было отмечено выше, многофункциональный характер, охватывающий широкий спектр социальных отношений внутри маленьких якутских сел. Появление домов Арчы свидетельствует не только об улучшении благосостояния якутских сел, но, что более важно, о консолидации сельских жителей, их готовности к созидательной работе.

Изучив все вышеперечисленные этнокультурные сооружения, уже можно наблюдать определенные различия и сходства между ними. Так, мы можем грубо классифицировать их по основам архитектурных форм на многоугольные срубы, урасовидные постройки, балаганы и купольный храм. На основе 
вышесказанного стоит сказать, что по архитектурной форме этнокультурные сооружения часто напоминают нам традиционные виды якутского жилища, иногда имеются пристройки для хозяйственного пространства.

Большинство описанных этнокультурных сооружений является мультифункциональными и могут выполнять как религиозные, так и культурно-просветительские, образовательные, целительные функции, могут быть местом проведения собраний, кружков, концертов, использоваться как конференц-зал и т.д. И большинство Арчы Дьиэтэ выступают как центры духовного и народного творчества.

Несомненно одно: изучение такого рода явления в культурном ландшафрте современной Якутии является ключом для изучения важного феномена духовной культуры - ревитализации традиций и проявлений традиционализма. Новые этнокультурные сооружения стали для якутов символом традиционного прошлого, местом, где они чувствуют свою причастность к нему. Арчы Дьиэтэ - этнокультурные сооружения современных якутов - выступают олицетворением представлений народа о своей традиционной культуре, ее облике, и функциональном содержании. Являются некими маяками в определении своей этничности.

\section{Литература}

1. Бабаков В.Г. Кризисные этносы / В.Г. Бабаков; Рос. АН, Ин-т философии. М.: ИФРАН, 1993. $183 \mathrm{c.}$

2. Брагина Д.Г. Трансорормация традиционной культуры якутов: (конец XX начало XXI в.) / Д.Г. Брагина. Новосибирск: Наука, 2016. 120 с.

3. Бысыгысов Р. "Мы не сектанты": Кто и зачем проводит мужской алгыс в Доме Арчы // Сетевое издание "Якутское-Саха Информационное Агентство", [Электронный pecypc]. URL.: http://ysia.ru/my-ne-sekta-kto-i-zachem-provodit-muzhskoj-algys-v-domearchy/ (дата обращения: 10.09.2021).

4. Веденин Ю.А., Кулешова М.Е.: Культурный ландшафт как объект культурного и природного наследия / Ю.А. Веденин, М.Е. Кулешова // Известия РАН. Сер. Геогр. 2001. № 1. С. 7-14.

5. Гоголев А.И. Историческая этнография якутов: Вопросы происхождения якутов : учеб. пос. / А.И. Гоголев. Якутск: Изд-во Якут. гос. ун-та, 1986. 92 с.

6. Гоголев А.И. Якуты (проблемы этногенеза и формирование этнокультуры) / А.И. Гоголев. Якутск: Изд-во ЯГУ, 1993. 267 с.

7. Дирин Д.А. Основные подходы к исследованию культурных ландшафтов в российской культурной географии / Д.А. Дирин //Социально-экономический географический Вестник Ассоциации географов-обществоведов. 2015. № 1. С. 24-37.

8. Зыков Ф.М. Поселения, жилища и хозяйственные постройки якутов (XIX-начало ХХ в.). Историко-этнографическое исследование / Ф.М. Зыков. Новосибирск: Наука, $1986.108 \mathrm{c}$.

9. Кузьмина Н.В. Культурные ландшафрты российских мегаполисов: символико-семиотический аспект // Урбанистика. 2018. № 1. С. 51-58. [Электронный ресурс] URL: https://nbpublish.com/library_read_article.php?id=25394 дата обращения: (08.03.2020).

10. Леви-Стросс К. Структурная антропология / К. Леви-Стросс; [Пер. с фрр. Под ред. и с примеч. В.В. Иванова]. М.: Изд-во ЭКСМО-Пресс, 2001. 512 с.

11. Маак Р.К. Вилюйский округ / Р.К. Маак; [Предисл. С.А. Степанова]. [2-е изд.] М.: АО "ЯНА", 1994. 576 с.

12. Миддендорф А.Ф: Путешествие на Север и восток Сибири: Ч. 2, вып. 7, отд. 6: Коренные жители Сибири: [перевод с немецкого / соч.] А. Миддендорфа. СПб: Типография Академии наук, 1878. С. 619-833. $31 \mathrm{c.}$

13. Носов M.M. Якутская берестяная ураса / М.М. Носов. Якутск: Бичик, 1954.

14. Серошевский В.Л. Якуты: Опыт этнографрического исследования / В.Л. Серошевский; [Предисл. С.А. Степанова, Коммент. М.Я. Жорницкой, Ш.Ф. Мухамедьярова]. [2-е изд.]. М.: Ассоц. "Рос. полит. энцикл.", 1993, XVIII, 712 с.

15. Сидорова Л.Е., Федорова Д.Ф. Семантика орнаментальных мотивов народов Саха / Л.Е. Сидорова, Д.Ф. Федорова // Науки и мир. 2020. № 12. С. 79-81.

16. О деятельности некоммерческих организаций / Информационный портал Министерства юстиции Российской Федерации [Электронный ресурс]. URL.: http://unro. minjust.ru/NKOs.aspx (дата обращения: 10.09.2021).

17. News.Ykt.Ru. Несколько сотен мужчин станцевали осуохай в центре Якутска // Новостная служба "Новости Якутии" [Электронный ресурc]. URL.: http://news.ykt.ru/ article/71735 (дата обращения: 10.09.2021). 


\section{Транслитерация по ГОСТ 7.79-2000 система Б}

1. Babakov V.G. Krizisnye ehtnosy / V.G. Babakov; Ros. AN, In-t filosofii. M.: IFRAN, 1993. $183 \mathrm{~s}$.

2. Bragina D.G. Transformatsiya traditsionnoj kul'tury yakutov: (konets XX - nachalo XXI v.) / D.G. Bragina. Novosibirsk: Nauka, 2016. 120 s.

3. Bysygysov R. "My ne sektanty": Kto i zachem provodit muzhskoj algys v Dome Archy // Setevoe izdanie "YAkutskoe-Sakha Informatsionnoe Agentstvo", [EHlektronnyj resurs]. URL.: http://ysia.ru/my-ne-sekta-kto-i-zachem-provodit-muzhskoj-algys-v-domearchy/ (data obrashheniya: 10.09.2021).

4. Vedenin YU.A., Kuleshova M.E.: Kul'turnyj landshaft kak ob"ekt kul'turnogo i prirodnogo naslediya / YU.A. Vedenin, M.E. Kuleshova // Izvestiya RAN. Ser. Geogr. 2001. № 1 . S. 7-14.

5. Gogolev A.I. Istoricheskaya ehtnografiya yakutov: Voprosy proiskhozhdeniya yakutov : ucheb. pos. / A.I. Gogolev. YAkutsk: Izd-vo YAkut. gos. un-ta, 1986. 92 s.

6. Gogolev A.I. YAkuty (problemy ehtnogeneza i formirovanie ehtnokul'tury) / A.I. Gogolev. YAkutsk: Izd-vo YAGU, 1993. $267 \mathrm{~s}$.

7. Dirin D.A. Osnovnye podkhody k issledovaniyu kul'turnykh landshaftov v rossijskoj kul'turnoj geografii / D.A. Dirin //Sotsial'no-ehkonomicheskij geograficheskij Vestnik Assotsiatsii geografov-obshhestvovedov. 2015. № 1. S. 24-37.

8. Zykov F.M. Poseleniya, zhilishha i khozyajstvennye postrojki yakutov (XIX-nachalo KHKH v.). Istoriko-ehtnograficheskoe issledovanie / F.M. Zykov. Novosibirsk: Nauka, 1986. $108 \mathrm{~s}$.

9. Kuz'mina N.V. Kul'turnye landshafty rossijskikh megapolisov: simvoliko-semioticheskij aspekt // Urbanistika. 2018. № 1. S. 51-58. [EHlektronnyj resurs] URL: https:// nbpublish.com/library_read_article.php?id=25394 data obrashheniya: (08.03.2020).

10. Levi-Stross K. Strukturnaya antropologiya / K. Levi-Stross; [Per. s fr. Pod red. i s primech. V.V. Ivanova]. M.: Izd-vo EHKSMO-Press, 2001. $512 \mathrm{s.}$

11. Maak R.K. Vilyujskij okrug / R.K. Maak; [Predisl. S.A. Stepanova]. [2-e izd.] M.: AO "YANA", 1994. $576 \mathrm{~s}$.

12. Middendorf A.F: Puteshestvie na Sever i vostok Sibiri: CH. 2, vyp. 7, otd. 6: Korennye zhiteli Sibiri: [perevod s nemetskogo / soch.] A. Middendorfa. SPb: Tipografiya Akademii nauk, 1878. S. 619-833.

13. Nosov M.M. YAkutskaya berestyanaya urasa / M.M. Nosov. YAkutsk: Bichik, 1954. $31 \mathrm{~s}$.

14. Seroshevskij V.L. YAkuty: Opyt ehtnograficheskogo issledovaniya / V.L. Seroshevskij; [Predisl. S.A. Stepanova, Komment. M.YA. ZHornitskoj, SH.F. Mukhamed'yarova]. [2-e izd.]. M.: Assots. "Ros. polit. ehntsikl.", 1993, XVIII, 712 s.

15. Sidorova L.E., Fedorova D.F. Semantika ornamental'nykh motivov narodov Sakha / L.E. Sidorova, D.F. Fedorova // Nauki i mir. 2020. № 12. S. 79-81.

16. O deyatel'nosti nekommercheskikh organizatsij / Informatsionnyj portal Ministerstva yustitsii Rossijskoj Federatsii [EHlektronnyj resurs]. URL.: http://unro.minjust.ru/ NKOs.aspx (data obrashheniya: 10.09.2021).

17. News.Ykt.Ru. Neskol'ko soten muzhchin stantsevali osuokhaj v tsentre YAkutska // Novostnaya sluzhba "Novosti YAkutii" [EHlektronnyj resurs]. URL.: http://news.ykt.ru/ article/71735 (data obrashheniya: 10.09.2021). 
Яковлев А. И., Федорова А. Р., Егоров А. Ф. О "новых" әтнокультурных сооружениях Якутии.

Сегодня в Якутии, наблюдается рост интереса к традиционной культуре. Этот возрастающий интерес к родной культуре (традиции, одежде, повседневным и праздничным ритуалам) можно охарактеризовать как процесс ревитализации традиций. В Якутии процесс ревитализации традиционной культуры основа широкого спектра социокультурных процессов в жизни якутян, таких как ренессанс традиционализма - с одной стороны (нео)мифология, (нео)язычество, с другой стороны, якутский кинематограф, Театр Олонхо, различные культурные мероприятия в городах и крупных селах Якутии). Эти процессы находят отражение в культурном ландшафте современной Якутии в виде новых этнокультурных традиционных сооружений.

Ключевые слова: (нео)традиционализм, современные культовые сооружения, ревитализация культуры, этнокультурный традиционализл, якутыь

Yakovlev A. I., Fedorova A. R., Egorov A. F. On the "new" ethnocultural buildings in Yakutia.

Today in Yakutia, there is a growing interest in traditional culture. This growing interest in the native culture (traditions, clothing, everyday and holiday rituals) can be characterized as a process of revitalizing traditions. In Yakutia, the process of revitalizing traditional culture is the basis of a wide range of socio-cultural processes in the life of the Yakut people, such as the renaissance of traditionalism - on the one hand, (neo)mythology, (neo)paganism, on the other hand, Yakut cinema, The Olonkho Theater, various cultural events in cities and large villages of Yakutia). These processes are reflected in the cultural landscape of modern Yakutia in the form of new ethnocultural traditional structures.

Key words: (neo)traditionalism, modern cult buildings, revitalization of culture, ethnocultural traditionalism, Yakuts

Для цитирования: Яковлев А. И., Федорова А. Р., Егоров А. Ф. О "новых" этнокультурных сооружениях Якутии // Ойкумена. Регионоведческие исследования. 2021. № 4. С. 99-109. DOI: $10.24866 / 1998-6785 / 2021-4 / 99-109$

For citation: Yakovlev A. I., Fedorova A. R., Egorov A. F. On the "new" ethnocultural buildings in Yakutia // Ojkumena. Regional researches. 2021. № 4. P. 99-109. DOI: 10.24866/19986785/2021-4/99-109 